\title{
Epidemiological, clinical and pathological evaluation of overall survival in canines with mammary neoplasms
}

\author{
[Estudo epidemiológico, clínico-patológico e avaliação de sobrevida global em cadelas com \\ neoplasias mamárias] \\ F.C. Nunes ${ }^{1}$, C.B. Campos $^{2}$, S.V. Teixeira ${ }^{1}$, A.C. Bertagnolli ${ }^{3}$, \\ G.E. Lavalle $^{4}$, G.D. Cassali $^{1 *}$ \\ ${ }^{1}$ Universidade Federal de Minas Gerais - Instituto de Ciências Biológicas - Belo Horizonte, MG \\ ${ }^{2}$ Division of Hematology and Oncology - Mayo Clinic - Scottsdale - AZ, USA \\ ${ }^{3}$ Instituto de Pesquisas Veterinárias Desidério Finamor - Eldorado do Sul, RS \\ ${ }^{4}$ Universidade Federal de Minas Gerais - Escola de Veterinária - Belo Horizonte, MG
}

\begin{abstract}
Canine mammary neoplasms (CMNs) are the most frequent lesions and in female dogs. However, studies correlating pathological criteria with clinical evolution in female dogs with mammary neoplasms are scarce. The present study aims to present epidemiological, clinical-pathological and overall survival data to help establish the prognosis and understand the biological behavior of CMNs. A total of 1539 cases were included ( $85 \%$ malignant and $13 \%$ benign). Tumor size was an important prognostic factor and was associated with overall patient survival $(\mathrm{P}<0.0001)$. Most dogs diagnosed with malignant neoplasms $(83 \%)$ had initial clinical staging, although $17 \%$ had regional or distant metastases at the time of diagnosis and lower overall survival $(\mathrm{P}<$ 0.0001). Carcinoma in mixed tumor was the most frequent histological type and had a better prognosis. Solid carcinomas, micropapillary carcinomas and carcinosarcomas were considered histological types with aggressive biological behavior and were associated with a worse prognosis and lower overall survival $(\mathrm{P}<$ $0.0001)$.
\end{abstract}

Keywords: female dogs, mammary gland, carcinomas, prognosis

\section{RESUMO}

Neoplasias mamárias caninas (NMCs) são as lesões mais frequentes em cadelas. Estudos que correlacionam os critérios patológicos com a evolução clínica em cadelas com neoplasias mamárias são escassos. Este estudo objetiva apresentar dados epidemiológicos, clínico-patológicos e de sobrevida global fornecendo informações que auxiliam a estabelecer o prognóstico e a compreender o comportamento biológico de NMCs. Foram incluídos 1539 casos, 85\% malignos e 13\% benignos. O tamanho tumoral foi um importante fator prognóstico, sendo associado com a sobrevida global das pacientes $(P<0,0001)$. A maioria das cadelas diagnosticadas com neoplasias malignas (83\%) apresentavam estadiamentos clínicos iniciais, enquanto $17 \%$ apresentavam metástases regionais ou à distância no momento do diagnóstico, denotando menor sobrevida global $(P<0,0001)$. O carcinoma em tumor misto foi o tipo histológico mais frequente e de melhor prognóstico. Os carcinomas sólidos, carcinomas micropapilares e carcinossarcomas foram considerados tipos histológicos de comportamento biológico agressivo, sendo associados a pior prognóstico e menor sobrevida global $(P<0,0001)$.

Palavras-chave: cadelas, glândula mamária, carcinomas, prognóstico

\section{INTRODUCTION}

Female canine mammary neoplasms (CMNs) are the most frequent lesions in non-spayed female

Recebido em 9 de agosto de 2017

Aceito em 3 de fevereiro de 2018

* Autor para correspondência (corresponding author)

E-mail: cassalig@icb.ufmg.br dogs (Brodey et al., 1983). CMNs represent approximately $50 \%$ of the diagnoses in canine females (Von Euler, 2011). Age, hormonal exposure, breed, diet and obesity influence the risk of developing CMNs (Sorenmo et al., 2013). 
Histologically, approximately $50 \%$ of CMNs are classified as malignant, and distant metastases are the main cause of death (Sorenmo, 2003). A number of clinical and pathological factors, including tumor size (greater than $3.0 \mathrm{~cm}$ ), undifferentiated, ulcerated, adherent tumors, with a diagnosis of solid, anaplastic, inflammatory carcinomas or sarcomas, regional or distant metastases, vascular or lymphatic invasion, absence of hormone receptor expression and high proliferation rates are associated with a worse prognosis (Von Euler, 2011).

Knowledge of prognostic factors is important for the determination of therapeutic programs for cancer patients, because this knowledge allows the application of the different therapeutic modalities used in mammary cancer with adequate and individualized intensity and effectiveness (Abreu and Koifman, 2002). However, studies correlating the pathological criteria with clinical evolution in female dogs with mammary neoplasms are scarce. Therefore, this study aims to present epidemiological, clinical-pathological and overall survival data to elucidate the biological behavior of CMNs.

\section{MATERIALS AND METHODS}

The protocols for the care of dogs diagnosed with mammary neoplasms seen at the Veterinary Hospital of the Federal University of Minas Gerais (Universidade Federal de Minas Gerais UFMG) from 2000 to 2015 were analyzed. All patients were initially subjected to surgical excision of the mammary gland lesion. The histopathological diagnosis was performed by the Laboratory of Comparative Pathology of the Biological Sciences Institute of the UFMG. All procedures were performed under the appropriate guidelines and with the approval of the Ethics Committee for Animal Experimentation (CETEA/UFMG), protocol number 338/2012.

Information epidemiological, clinicalpathological were obtained through medical records. All patients were subjected to complementary examinations, including chest radiographs in three planes (right latero-lateral, left latero-lateral and ventro-dorsal), abdominal ultrasound and serum exams (complete blood count, coagulogram and hepatic and renal profiles).
The cases were staged according to the tumornode-metastasis (TNM) clinical staging system for canine mammary tumors: this system evaluates tumor size $\left(\mathrm{T}_{1}, 0-3 \mathrm{~cm} ; \mathrm{T}_{2}, 3-5 \mathrm{~cm}\right.$; $\left.\mathrm{T}_{3},>5 \mathrm{~cm}\right)$; the involvement of regional lymph nodes $\left(\mathrm{N}_{0}\right.$, no metastasis; $\mathrm{N}_{1}$, metastasis), and the presence of distant metastasis $\left(\mathrm{M}_{0}\right.$, no metastasis; $\mathbf{M}_{1}$, metastasis). Cases were then categorized into five stages: I $\left(\mathrm{T}_{1} \mathrm{~N}_{0} \mathrm{M}_{0}\right) ;$ II $\quad\left(\mathrm{T}_{2} \mathrm{~N}_{0} \mathrm{M}_{0}\right) ;$ III $\left(\mathrm{T}_{3} \mathrm{~N}_{0} \mathrm{M}_{0}\right)$; IV $\left(\mathrm{T}_{1,2,3} \mathrm{~N}_{1} \mathrm{M}_{0}\right)$; and $\mathrm{V}\left(\mathrm{T}_{1,2,3} \mathrm{~N}_{0},{ }_{1} \mathrm{M}_{1}\right)$ (Owen, 1980; Sorenmo et al., 2013). Then, the animals were classified into initial (I-III) and advanced (IV-V) clinical staging.

All tumors were fixed in $10 \%$ buffered formalin, paraffin embedded and routinely prepared and stained with hematoxylin and eosin (HE). Tumors were classified according to Consensus for the diagnosis, prognosis and treatment of canine mammary tumors (Cassali et al., 2014, Cassali et al., 2017). When the dog had multiple masses, the worst prognostic tumor was chosen for the analysis. Furthermore, tumors were graded according to the Nottingham Grading System (Elston and Ellis, 1998).

After surgery, the patients were followed up every three months during the first year and every six months for a minimum period of 24 months. In cases where there was loss of follow up of the clinical follow-up by the patient's guardian, telephone contact with the owners was made to obtain information about the animal. The overall survival was defined as the period in days between the surgical excision of the tumor and the death due to the tumor. Animals whose death occurred for unknown reasons or causes not related to the tumor and animals lost to follow-up were excluded from the study.

Comparisons of categorical variables were performed using the Chi-square or Fisher's exact method. Continuous variables were assessed using Student's t-test, and overall survival was estimated using Kaplan-Meier curves. The analyses were estimated using the Prism 5.0 (Graph Pad Inc., CA, USA). Comparisons between groups were performed using the Cox Mantel log-rank test. Values of $\mathrm{P}<0.05$ were considered significant. 


\section{RESULTS}

A total of 1539 cases were included, nonneoplastic lesions represented 2\% (28/1539) of the cases, $13 \%(201 / 1539)$ were classified as benign neoplasms, and 85\% (1310/1539) were malignant neoplasms. Only four males $(0.26 \%)$ were diagnosed with NMCs, of which $75 \%(3 / 4)$ presented malignant neoplasia and 25\% (1/4) benign neoplasia. The ages ranged from 2 to 20 years, with a mean of $9.82 \pm 2.79$ years at diagnosis. Purebred animals accounted for $77 \%$ $(1106 / 1435)$ of the cases and 23\% (329/1435) were considered to have a mixed breed. Most of the female dogs were intact $(72 \%)$ and had a normal estrous cycle $(72 \%)$ and a history of pseudocyesis $(59 \%)$ at the time of diagnosis. The administration of hormones was infrequent $(7 \%$ of the cases).
Female dogs with malignant neoplasms were significantly older, with a mean age of $10.74 \pm 2.75$ years, whereas the female dogs with benign neoplasms had an average age of $8.43 \pm 2.77$ years $(\mathrm{P}<0.0001)$. Most lesions were found in the caudal abdominal and inguinal mammary glands [25\% (318/1297) and 33\% (432/1297), respectively]. The majority of the benign neoplasms $(76 \%)$ and half of the malignancies were smaller than $3.0 \mathrm{~cm}$ in diameter. Adherence was observed in $10 \%$ $(135 / 1307)$ of female dogs with malignant mammary neoplasms, ulceration was observed in $6 \%(77 / 1300)$, and relapse was observed in $3 \%$ (37/1273). Epidemiological and clinicalpathological information for the neoplasms studied is detailed in Table 1.

Table 1. Epidemiological and clinical-pathological information for the benign and malignant neoplasms of the mammary gland in dogs

\begin{tabular}{|c|c|c|c|}
\hline & $\begin{array}{l}\text { Benign neoplasms } \\
\quad(\mathrm{n}=201)\end{array}$ & $\begin{array}{l}\text { Malignant neoplasms } \\
(\mathrm{n}=1310)\end{array}$ & $P$ value \\
\hline Age $($ mean \pm SD) & $8.43 \pm 2.77$ & $10.74 \pm 2.75$ & 0.0001 \\
\hline \multicolumn{4}{|l|}{ Breed } \\
\hline Mixed breed & $33(18 \%)$ & $296(24 \%)$ & \multirow[t]{2}{*}{0.0629} \\
\hline Pure race & $155(82 \%)$ & $951(76 \%)$ & \\
\hline \multicolumn{4}{|l|}{ Reproductive status } \\
\hline Intact & $54(71 \%)$ & $565(72 \%)$ & \multirow[t]{2}{*}{0.7905} \\
\hline Neutered & $22(29 \%)$ & $217(28 \%)$ & \\
\hline \multicolumn{4}{|l|}{ Pseudocyesis } \\
\hline Present & $33(55 \%)$ & $332(59 \%)$ & \multirow[t]{2}{*}{0.68} \\
\hline Absent & $27(45 \%)$ & $235(41 \%)$ & \\
\hline \multicolumn{4}{|l|}{ Estrous Cycle } \\
\hline Regular & $41(73 \%)$ & $421(72 \%)$ & \multirow[t]{2}{*}{0.8777} \\
\hline Irregular & $15(27 \%)$ & $165(28 \%)$ & \\
\hline \multicolumn{4}{|c|}{ Administration of hormones } \\
\hline Present & $3(6 \%)$ & $41(7 \%)$ & \multirow[t]{2}{*}{10} \\
\hline Absent & $50(94 \%)$ & $524(93 \%)$ & \\
\hline \multicolumn{4}{|l|}{ Adherence } \\
\hline Present & $1(1 \%)$ & $135(10 \%)$ & \multirow[t]{2}{*}{0.0001} \\
\hline Absent & $200(99 \%)$ & $1172(90 \%)$ & \\
\hline \multicolumn{4}{|l|}{ Ulceration } \\
\hline Present & $3(1 \%)$ & $77(6 \%)$ & \multirow[t]{2}{*}{0.0064} \\
\hline Absent & $198(99 \%)$ & $1223(94 \%)$ & \\
\hline \multicolumn{4}{|l|}{ Relapse } \\
\hline Present & 0 & $37(3 \%)$ & \multirow[t]{2}{*}{0.0103} \\
\hline Absent & $204(100 \%)$ & $1273(97 \%)$ & \\
\hline \multicolumn{4}{|l|}{ Location of the tumor } \\
\hline Cranial thoracic & $10(5 \%)$ & $63(6 \%)$ & \multirow[t]{6}{*}{0.0536} \\
\hline Caudal thoracic & $18(10 \%)$ & $158(14 \%)$ & \\
\hline Cranial abdominal & $19(10 \%)$ & $167(15 \%)$ & \\
\hline Caudal abdominal & $45(25 \%)$ & $278(25 \%)$ & \\
\hline Inguinal & $78(42 \%)$ & $346(32 \%)$ & \\
\hline Multicenter & $14(8 \%)$ & $92(8 \%)$ & \\
\hline \multicolumn{4}{|l|}{ Tumor size } \\
\hline $\mathrm{T}_{1}(<3 \mathrm{~cm})$ & $124(76 \%)$ & $539(50 \%)$ & \multirow[t]{3}{*}{0.0001} \\
\hline $\mathrm{T}_{2}(>3$ and $<5 \mathrm{~cm})$ & $22(14 \%)$ & $237(22 \%)$ & \\
\hline $\mathrm{T}_{3}(>5 \mathrm{~cm})$ & $17(10 \%)$ & $304(28 \%)$ & \\
\hline
\end{tabular}


In dogs diagnosed with malignant neoplasms, a significant association was observed between the tumor size and overall survival time $(\mathrm{P}<0.0001)$. The $\mathrm{T}_{1}$ and $\mathrm{T}_{2}$ groups did not reach the median, whereas the $\mathrm{T}_{3}$ group presented lower survival, with a median of 1149 days (Figure 1A).

Initial clinical staging (I-III) was described in $83 \%(871 / 1045)$ of the female dogs with malignant neoplasms, and $17 \%(174 / 1045)$ of the female dogs were classified in advanced clinical staging (IV-V). Female dogs in the initial clinical stage had a longer overall survival time, and the median survival was not reached; female dogs with regional lymph node metastases had a median survival time of 331 days, and female dogs with distant metastasis had a median survival time of 236 days $(\mathrm{P}<0.0001)$ (Figure 1B).

Ductal ectasia and benign mixed tumors were the most frequent tumors in the non-neoplastic lesions and benign neoplasms, respectively. Malignant neoplasms presented carcinoma in a mixed tumor as the most frequent histological type, followed by solid carcinoma and invasive papillary carcinoma. Among the special carcinoma types, micropapillary carcinoma was more frequent. Malignant neoplasms of epithelial and mesenchymal origin accounted for $4 \%$ of the cases with the carcinosarcoma histological type (Table 2).

Female dogs diagnosed with carcinoma in mixed tumors, invasive papillary carcinomas and tubular carcinomas had longer survival times and did not reach the median compared to female dogs with solid carcinomas (median at 268 days), micropapillary carcinomas (median at 120 days) and carcinosarcomas (median at 113 days) ( $\mathrm{P}<$ 0.0001) (Figure 1C). A histological grade examination was performed in 228 cases of malignant neoplasms, of which $37 \%$ (84/228) were classified as grade I, 39\% (90/228) as grade II and $24 \%(54 / 228)$ as grade III. In the overall survival evaluation, female dogs with neoplasms with histological grades I and II had the highest overall survival and did not reach the median. However, the overall survival was lower (median 504 days) for female dogs with neoplasms with histological grade III $(\mathrm{P}=0.0005)$ (Figure 1D).
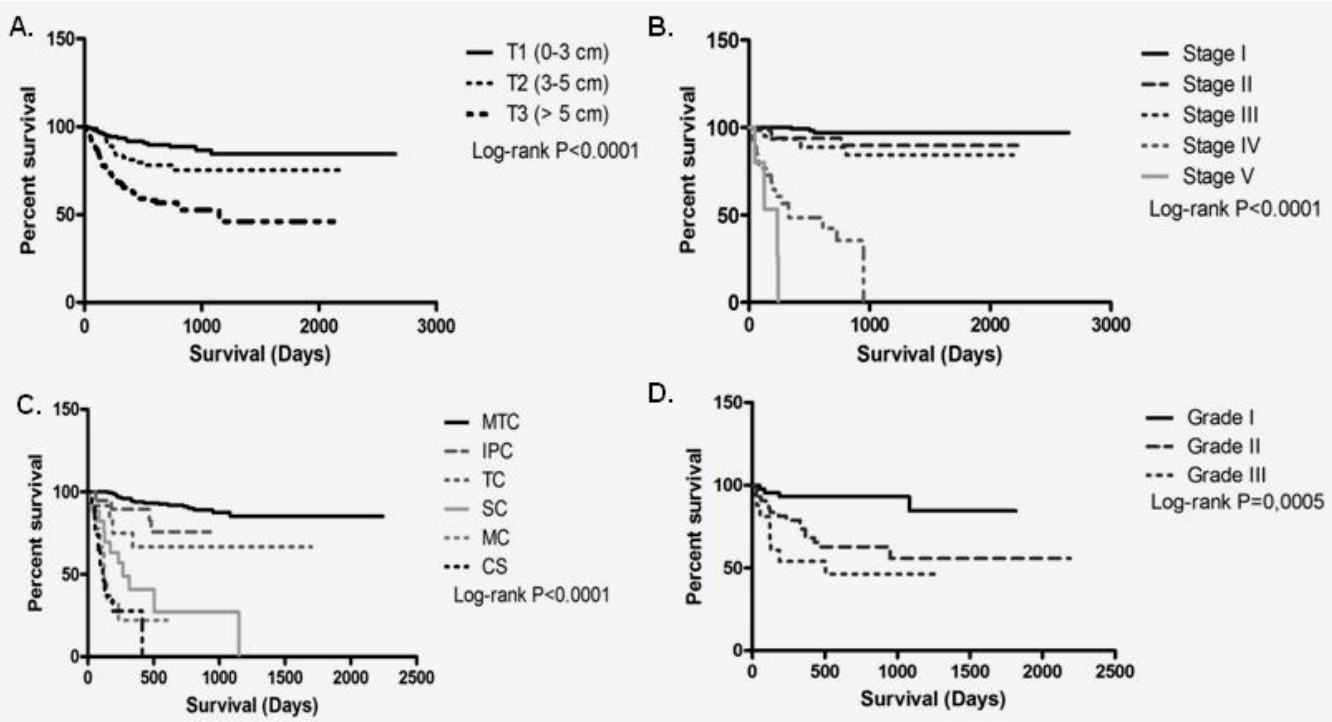

Figure 1. Overall survival curve derived from the Kaplan-Meier analysis of female dogs with malignant mammary neoplasms. A. Malignant mammary neoplasms classified by tumor size as follows: T1:142; T2: 88 and T3: 128 cases, respectively. B. Malignant mammary neoplasms classified according to the clinical stage as follows: Stage I ( $n=$ 132); Stage II $(n=69)$ and Stage III $(n=65)$, which did not reach the median. Stage IV $(n=30)$ had a median survival of 331 days and Stage V $(n=5)$ had a median survival of 236 days. C. Malignant mammary neoplasms classified by histological type. MTC: carcinoma in mixed tumor $(n=212)$, IPC: invasive papillary carcinoma $(n=19)$ and TC: tubular carcinoma $(n=14)$, did not reach the median; MC: micropapillary carcinoma $(n=9)$, SC: solid carcinoma $(n=$ 18), and CS: carcinosarcoma $(n=13)$, median 120,268 and 113 days, respectively. D. Malignant mammary neoplasms classified according to histological grade. Grade I $(n=44)$ and Grade II $(n=43)$ did not reach the median and Grade III $(\mathrm{n}=18)$ median at 504 days. 
Table 2. Classification and frequency of mammary tumors in female dogs seen at the UFMG veterinary hospital

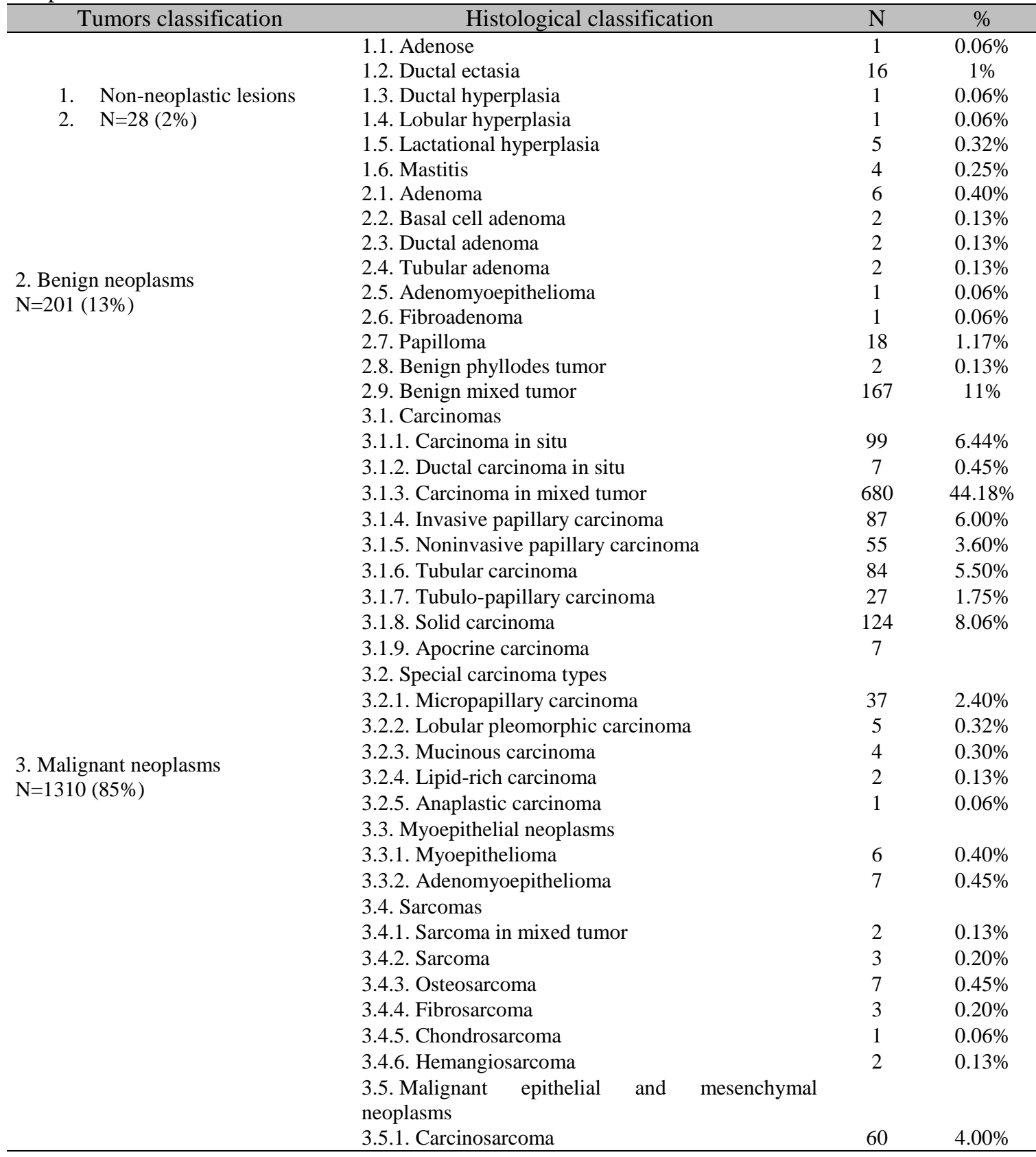

Approximately 41\% (535/1310) of the malignant neoplasms had clinical follow-up (maximum follow-up of 84 months). Of the neoplasms with follow-up, $2 \%(11 / 535)$ had clinical presentation of inflammatory carcinoma, 7\% (37/535) presented recurrence alone, and 13\% (70/535) presented relapse and/or distant metastases. The lung was the main metastatic site $(81 \%, 57 / 70)$, followed by bone tissue, the central nervous system and liver $(6 \%, 4 / 64$ for each) and the kidney $(1 \%, 1 / 64)$.

\section{DISCUSSION}

The mean age observed in the female dogs in the present study was similar to the mean age described in the literature, with higher susceptibility between 9 and 11 years (Sorenmo 
et al., 2013). The low occurrence of mammary neoplasms in male dogs corroborated previous studies that reported a frequency between 0 and 2.7\% (Brodey et al., 1983; Bearss et al., 2012). Some authors reported a lack of predisposition according to race (Peleteiro, 1994; Queiroga and Lopes, 2002). In the present study, pure race predominated, corresponding to the most frequent races in the place where the study was performed.

Ovariohysterectomy was not commonly found in the evaluated animals, resulting in a greater number of non-spayed female dogs at the time of diagnosis. Policies to clarify and encourage early spaying should be adopted to raise awareness among the population and prevent mammary cancers in female dogs. Early spaying prevents mammary cancer when performed up to 2.5 years of age. The risk of mammary tumor development is $0.5 \%$ for spayed dogs before the first estrus, $8 \%$ before the second estrus and $26 \%$ after the second estrus (Schneider et al., 1969). The administration of hormones and irregular estrus cycles were not related to the frequency of malignant mammary neoplasms in this study. Few owners reported regular use of estrusregulating hormones or abortion drugs in the study population. There is no evidence that irregular estrus cycles influence the development of mammary tumors (Peleteiro, 1994). However, the long-term use of contraceptives promotes the formation of hyperplastic nodules that can undergo malignant transformation (Misdorp, 1991).

Studies in other countries indicate that between 41 and $53 \%$ of mammary tumors are described as malignant (Brodey et al., 1983; Von Euler, 2011). However, in Brazil, the frequency of malignant neoplasms varies between 68 and $90 \%$ (Oliveira et al., 2010; Toríbio et al., 2012), which is similar to the prevalence observed in this study. The higher frequency of malignant CMNs may be associated with the criteria for the evaluation of neoplasms of the mammary gland, in this study all the areas were rigorously evaluated including in situ, microinvasive and invasive areas, contributing to an increased diagnosis of malignant neoplasms. In addition, the delay of the tutors by the search for care, may have resulted in long periods leading to the progression of the disease to advanced stage. Prolonged times allow mammary neoplasms to progress from benign lesions to invasive malignant lesions (Ferreira et al., 2009; Sorenmo et al. 2009). The high rate of malignancy observed is also associated with a higher frequency of mixed neoplasms. Mixed tumors are the most frequent neoplasms of mammary glands in female dogs (Cassali et al., 2012). These tumors may undergo malignant transformation and give rise to carcinoma in mixed tumor, carcinosarcomas and sarcomas in a mixed tumor (Misdorp et al., 1999; Cassali et al., 2012; Cassali et al., 2014; Cassali et al., 2017).

The female dogs with malignant neoplasms were older, corroborating other authors who described the appearance of benign mammary neoplasms in young female dogs (Peleteiro, 1994). Misdorp (2002) reported that more caudal mammary glands were more affected due to a greater amount of mammary parenchyma and consequently a greater proliferative response to the action of hormones, which corroborated our findings. In this study, tumor size was an important prognostic factor associated with longer survival in female dogs with smaller lesions. Similar results were reported by other authors. Yamagami et al. (1996) described a worse prognosis for animals with large size cancers $\left(\mathrm{T}_{2}\right.$ and $\left.\mathrm{T}_{3}\right)$, and Ferreira et al. (2009) observed an association between lesions greater than $5.0 \mathrm{~cm}$ and malignancy, higher rates of cell proliferation and lower hormone receptor expression. Given the importance of the size of the tumor, this approach, which is simple and has a low cost, should be routine for female dogs with mammary tumors because it helps determine the patient's prognosis. In addition to providing a prognosis, the evaluation of tumor size allows selection of the surgical approach and directs the choice of individual treatment for each patient by the oncologists. Thus, all bitches with breast tumors, even with small lesions, should be evaluated, submitted to surgery and the material sent for histopathological examination, since early diagnosis increases the chances of cure.

Previous studies have reported a lower survival rate in animals presenting regional lymph node metastases (stage IV) compared to animals without lymph node involvement (Araujo et al., 2016), and worse prognoses were associated with distant metastases (stage V) compared to stages I-IV (Yamagami et al., 1996; Karayannopoulou 
et al., 2005), which corroborated our findings. The importance of evaluating the clinical staging in each patient is clear; thus, performing complementary imaging tests, such as chest Xrays in three planes, is essential for the evaluation of the presence of distant metastases. As mentioned by Sorenmo et al. (2013), a search for metastases in other organs should be performed according to the clinical signs observed in the patients. Additionally, the regional lymph node evaluation should be judicious, and a histopathological examination is imperative for the definitive diagnosis of metastasis. The identification of regional or distant metastases is clearly associated with a worse prognosis and suggests the adoption of adjuvant therapies to surgery in an attempt to increase overall survival.

Several classification methods for canine mammary tumors have been proposed (Misdorp et al., 1999; Goldschmidt et al. 2011; Cassali et al. 2014), which makes comparisons of studies on the biological characteristics of malignant neoplasms difficult (Sarli et al., 2002). The classification criteria adopted in the present study allowed an adequate histopathological diagnosis that was associated with the clinical evolution of the patient. Tumors of epithelial origin constituted the majority of the series, similar to the tumors described by Misdorp et al. (1999). In the present study, carcinoma in mixed tumor was the most frequent histological type, corroborating the findings of other authors (Ribeiro et al., 2012; Toríbio et al., 2012).

Queiroga and Lopes (2002) reported a higher survival rate in patients with mixed tumors. In situ carcinomas and adenocarcinomas presented a more favorable prognosis, whereas micropapillary carcinomas demonstrated extremely aggressive biological behavior with high metastasis rates for regional lymph nodes and lower overall survival (Gama et al., 2008; Gamba et al., 2013). In this study, carcinoma in mixed tumor, invasive papillary carcinomas and tubular carcinomas presented better prognoses. Micropapillary carcinomas, solid carcinomas and carcinosarcomas were histological types that were associated with a worse prognosis and lower overall survival. Therapeutic complementation with adjuvant therapies, such as maximum-tolerated dose chemotherapy, is suggested and may be beneficial to increase overall survival and interfere with disease progression.

The histological grade is an independent prognostic factor. Most malignant CMNs were associated with a low histological grade (I and II). A lower survival time was related to an increase in anaplasia, with grade III presenting lower overall survival. Karayannopoulou et al. (2005) observed that female dogs with undifferentiated carcinomas (grade III) presented a worse prognosis than female dogs with grade I and II carcinomas. Ulceration, necrosis and recurrence were proposed as prognostic factors (Cassali et al., 2014), which corroborated the findings of this study because these characteristics showed a higher frequency in the malignant mammary neoplasms. Ulceration can be caused by invasive tumor growth, ischemia or skin infection, although these characteristics are not necessarily associated with aggressive biological behavior. The presence of distant metastases is more commonly found in the lungs (Von Euler, 2011), followed by the liver, kidneys, spleen, bones, central nervous system and pleura (Von Euler, 2011), as observed in the present study. These distant metastases are associated with a decrease in the patient's overall survival (Yamagami et al., 1996; Queiroga; Lopes, 2002).

\section{CONCLUSION}

An evaluation of the epidemiological, clinical and pathological characteristics is important to understand the population profile and biological behavior, to establish the prognosis of mammary neoplasms and to aid in the determination of the appropriate approach to the patient. Our results reinforce the importance of performing a tumor size evaluation, clinical staging, examining tumor malignancy characteristics, such as adhesion and ulceration, and determining the histological types in neoplasms of the female canine mammary gland. 


\section{REFERENCES}

ABREU, E.D.E.; KOIFMAN, S. Prognostic factors in woman breast cancer. Res. Bras. Cancerol., v.48, p.113-131, 2002.

ARAUJO, M.R.; CAMPOS, L.C.; DAMSCENO, K.A. et al. HER-2, EGFR, Cox-2 and Ki67 expression in lymph node metastasis of canine mammary carcinomas: Association with clinicalpathological parameters and overall survival. Res. Vet. Sci., v.106, p.121-130, 2016.

BEARSS, J.J.; SCHULMAN, F.Y.; CARTER, D. Histologic, immunohistochemical, and clinical features of 27 mammary tumors in 18 male dogs. Vet. Pathol., v.49, p.602-607, 2012.

BRODEY, R.S.; GOLDSCHMIDT, M.H.; ROSZEL, J.R. Canine mammary gland neoplasms. J. Am. Anim. Hosp. Assoc., v.19, p.61-90, 1983.

CASSALI, G.D.; CAVALHEIRO, A.B.; FERREIRA, E. et al. canine mammary mixed tumours : a review. Vet. Med. Int., v.2012, 2012.

CASSALI, G.D.; LAVALLE, G.E.; FERREIRA, E. et al. Consensus for the diagnosis, prognosis and treatment of canine mammary tumors. Braz. J. Vet. Pathol., v.4, p.153-180, 2014.

CASSALI, G.D.; DAMASCENO, K.A.; BERTAGNOLLI, A.C. et al. Consensus regarding the diagnosis, prognosis and treatment of canine mammary tumors: benign mixed tumors, carcinomas in mixed tumors and carcinosarcomas. Braz. J. Vet. Pathol, v. 10, p. 87-99, 2017.

ELSTON, C.W.; ELLIS, I.O. Assessment of histological grade. In:_. (Eds.). Systemic pathology. London: Churchill Livingstone, 1998. p.365-384.

FERREIRA, E.; BERTAGNOLLI, A.C.; CAVALCANTI, M.F. et al. The relationship between tumour size and expression of prognostic markers in benign and malignant canine mammary tumours. Vet. Comp. Oncol., v.7, p.230-235, 2009.

GAMA, A.; ALVES, A.; SCHMITT, F. Identification of molecular phenotypes in canine mammary carcinomas with clinical implications: Application of the human classification. Virchows Arch., v.453, p.123-132, 2008.
GAMBA, C.O.; DIAS, E.J; RIBEIRO, L.G. et al. Histopathological and immunohistochemical assessment of invasive micropapillary mammary carcinoma in dogs: a retrospective study. Vet. J., v.196, p.241-246, 2013.

GOLDSCHMIDT, M.; PEÑA, L.; RASTTO, R.; ZAPPULLI, V. Classification and grading of canine mammary tumors. Vet. Pathol., v.48, p.117-131, 2011.

KARAYANNOPOULOU, M.; KALDRYMIDOU, E.; CONSTANTINIDIS, T.C.; DESSIRIS, A. Histological grading and prognosis in dogs with mammary carcinomas: application of a human grading method. J. Comp. Pathol., v.133, p.246-252, 2005.

MISDORP, W. Progestagens and mammary tumors in dogs and cats. Acta Endocrinol., v.125, p.27-31, 1991.

MISDORP, W. Tumors of the mammary gland. DJ M. Eds. Tumors in domestic animals. Ames: Blackwell, 2002. p.575-606.

MISDORP, W.; ELSE, R.W.; HELLME, N.E.; LIPSCOMB, T.P. Histological classification of mammary tumors of the dog and the cat. 2.ed. Washington: Armed Forces Institute of Pathology, 1999.

OLIVEIRA, F.; KOMMERS, G.D.; MASUDA, E.K. et al. Estudo retrospectivo de 1.647 tumores mamários em cães. Pesqui. Vet. Bras., v.30, p.177-185, 2010.

OWEN, L. TNM Classification of tumours in domestic animals. [New York]: WHO, 1980. p.152 .

PELETEIRO, M.C. Tumores mamários na cadela e na gata. Rev. Port. Ciênc. Vet., v.89, p.10-29, 1994.

QUEIROGA, F.; LOPES, C. Canine mammary tumours, research on new prognostic factors. Rev. Port. Ciênc. Vet., v.97, p.119-127, 2002.

RIBEIRO, G.M.; BERTAGNOLLI, A.C.; MALAGOLI, R. et al. Morphological aspects and immunophenotypic profiles of mammary carcinomas in benign-mixed tumors of female dogs. Vet. Med. Int., v. 2012, 
SARLI, G.; PREZIOSI, R.; BENAZZI, C. et al. Prognostic value of histologic stage and proliferative activity in canine malignant mammary tumors. J. Vet. Diagn. Invest., v.14, p.25-34, 2002.

SCHNEIDER, R.; DORN, C.R.; TAYLOR, D.O. Factors influencing canine mammary cancer development and postsurgical survival. J. Natl. Inst., v.43, p.1249-1261, 1969.

SORENMO, K. Canine mammary gland tumors. Vet. Clin. N. Am. Small Anim. Pract., v.33, p.573-596, 2003.

SORENMO, K.U.; DEANNA, R.W.; GOLDSMIDT, R.H. Tumors of the mammary gland. In: WITHROW, S.J.; VAIL, D.M. Withrow \& MacEwen's small animal clinical oncology. 5.ed. Philadelphia: Saunders Company, 2013. p.553-571.

SORENMO, K.U.; KRISTIANSEN, V.M.; COFONE, M.A. et al. Canine mammary gland tumours: a histological continuum from benign to malignant; clinical and histopathological evidence. Vet. Comp. Oncol., v.7, p.162-172, 2009.
TORÍBIO, J.M.; ESTRELA-LIMA, A.; MARTINS FILHO, E.F. et al. Caracterização clínica, diagnóstico histopatológico e distribuição geográfica das neoplasias mamárias em cadelas de Salvador, BA. Rev. Ceres, v.59, p.427-432, 2012.

VON EULER, H. Tumors of the mammary gland. In: DOBSON, J.M.; LASCELLES, B. (Eds.). BSAVA manual of canine and feline oncology. 3.ed. Gloucester: British Small Animal Veterinary Association, 2011. p.237-247.

YAMAGAMI, T.; KOBAYASHI, T.; TAKAHASHI, K.; SUGIYAMA, M. Prognosis for canine malignant mammary tumors based on TNM and histologic classification. J. Vet. Med. Sci., v.58, p.1079-1083, 1996. 